\title{
PENGEMBANGAN ENSIKLOPEDIA BUMI DAN ANTARIKSA SERTA KAITANNYA DENGAN AL QURAN UNTUK MAHASISWA PENDIDIKAN FISIKA
}

Adi Nugraha Putra ${ }^{1}$, Maison ${ }^{2}$, Nova Susanti ${ }^{3}$

${ }^{1,2,3}$ Program Studi Pendidikan Fisika FKIP Universitas Jambi, Jambi, Indonesia

Email: adi.keripiksingkong@gmail.com,

Info Artikel

Diterima:

4 Oktober 2018

Disetujui:

25 Maret 2019

Dipublikasikan:

30 Juni 2019

\begin{abstract}
Abstrak:
Penelitian bertujuan untuk mengembangkan ensiklopedia dan mengetahui persepsi mahasiswa terhadap penggunaan ensiklopedia Bumi dan Antariksa. Pengembangan Ensiklopedia menggunakan pengembangan model ADDIE. Subjek penelitian ini adalah ahli materi, ahli media dan mahasiswa pendidikan fisika sebanyak 39 mahasiswa. Instrumen penelitian yang digunakan lembar validasi dan angket. Teknik analisis data validitas kelayakan produk dihitung menggunakan formula Aiken. Ensiklopedia berisikan tiga bab materi yaitu: struktur bumi, sistem tata surya, asteroid dan komet. Materi dikaitkan dengan ayat $\mathrm{Al}$ Quran yang relevan. Hasil validasi ahli diperoleh skor kelayakan produk 0,8 dengan kategori cukup tinggi. Hasil uji persepsi mahasiswa diperoleh persentase $84,61 \%$ baik.
\end{abstract}

Kata kunci: Ensiklopedia, Bumi dan Antariksa, Al Quran

\begin{abstract}
:
Research aims to develop the encyclopedia and know the student's perception of the Encyclopedia of Earth and Space. The encyclopedia development uses the development of ADDIE models. Subjects of this study were material experts, media experts and physics education students as much as 39 students. Research instruments used validation sheets and quisionare. Data analysis techniques for product eligibility validity are calculated using formula Aiken. The encyclopedia contains three material chapters: Earth structure, Solar System, asteroid and comet. The material is associated with relevant Quranic verses. Expert validation results are obtained by product eligibility scores of 0.8 with high enough categories. Student perception test results gained a percentage of $84.61 \%$ good.
\end{abstract}

Keywords: Encyclopedia, earth and Space, Quran

\section{Copyright @ 2019 EduFisika: Jurnal Pendidikan Fisika}

\section{Pendahuluan}

Berisi latar belakang, rasional, dan atau Pendidikan di Indonesia erat kaitannya dengan Ilmu pengetahuan dan teknologi. Ilmu pengetahuan dan teknologi mengalami perkembangan dari tahun ke tahun seiring dengan perkembangan zaman. Perkembangan ilmu pengetahuan dan teknologi semakin mendorong upaya-upaya pembaruan dalam pemanfaatan hasil-hasil tekonogi dalam proses belajar (Arsyad dalam Huriawati, 2015). 
Proses belajar mengajar mahasiswa sering dihadapkan pada materi pembelajaran yang di luar pengalaman mahasiswa, hal tersebut menyebabkan proses pembelajaran yang sedang berlangsung tidak berjalan secara efektif. Oleh karena itu media pembelajaran menjadi salah satu komponen penting dalam sistem pembelajaran sebagai alat perantara informasi. Salah satunya dalam pembelajaran fisika. Dalam Pembelajaran fisika seringkali membuat mahasiswa merasa jenuh dalam mempelajarinya, rasa jenuh mahasiswa muncul karena kurangnya motivasi yang dilakukan oleh dosen pada saat proses pembelajaran berlangsung. Dosen sekurang-kurangnya dapat menggunakan alat yang murah dan efisien yang meskipun sederhana dan bersahaja, tetapi merupakan keharusan dalam upaya mencapai tujuan pengajaran yang dicapai (Arsyad dalam Huriawati, 2015).

Ditinjau dari aspek tujuan atau kemampuan dasar yang ingin dicapai, mata pembelajaran fisika menekankan pada penguasaan konsep dan saling keterkaitaannya untuk diterapkan pada pemecahan masalah. Ditinjau dari aspek materi, pembelajaran Fisika mancakup topik- topik sebagai berikut : Fisika Matematika (aspek numerik), mekanika, termofisika (panas), gravitasi, Teori pengukuran dan instrumentasi, listrik magnet, Optika, Akustik, Fisika Zat padat, Fisika Atom dan Mekanika Kuantum, Fisika Inti.

Fisika merupakan cabang ilmu yang menguraikan dan menganalisis struktur, peristiwa yang terjadi di alam, teknik dan lingkungan sekitar. Proses menguraikan dan menganalisis tersebut bertujuan untuk memahami gejala alam. Pada mata kuliah Bumi dan Antariksa, mahasiswa ditugaskan untuk membuat suatu resume yang nantinya berguna untuk mahasiswa mudah memahami materi pokok pada Bumi dan Antariksa. Seperti kita ketahui bahwa banyak bahan ajar yang dapat dijadikan sebagai bahan resume, salah satunya adalah Ensiklopedia. Namun, Ensiklopedia umunya berisi penjelasan kata-kata yang berdasarkan huruf abjad yang kemudian dicetak ke dalam bentuk buku, sehingga mahasiswa membutuhkan buku tambahan sebagai penunjang kuliah pada mata kuliah Bumi dan Antariksa agar mahasiswa menjadi lebih paham

Salah satu fenomena alam dalam kehidupan sehari-hari adalah fenomena terjadinya gerhana bulan. Pada awalnya manusia menganggap bahwa fenomena tersebut terjadi karena bulan dimakan oleh mahluk raksasa, dan mitos ini terjadi pada masyarakat Jawa. Sudut pandang Fisika khususnya Bumi dan Antariksa berbeda dengan mitos yang ada dikalangan masyarakat. Dalam pandangan fisika terjadinya gerhana bulan adalah karena letak Matahari, bumi, dan bulan terletak pada satu garis lurus yang mengakibatkan cahaya matahari tidak sampai pada bulan karena cahaya matahari tertutupi oleh bumi. Terdapat perbedaan yang sangat jauh antara mitos yang terjadi dikalangan masyarakat dan penjelasan dari sudut pandang fisika, hal ini membuktikan bahwa dalam memahami fenomena alam khususnya Bumi dan Antariksa perlu adanya kemampuan nalar yang tinggi.

Proses pembelajaran pada progam studi Pendidikan Fisika khususnya pada mata kuliah Bumi dan Antariksa masih sangat membutuhkan sumber belajar lain guna menunjang pembelajaran di rumah, selama ini mahasiswa mendapat sumber belajar melalui media online dan beberapa buku saja yang terdapat di perpustakaan Universitas Jambi. Proses belajar yang baik adalah jika dalam pembelajaran tersebut didukung dengan media pembelajaran dan media tersebut contohnya adalah buku. "Media pembelajaran dapat meningkatkan kualitas proses pembelajaran yang pada akhirnya diharapkan dapat meningkatkan hasil belajar yang dicapai oleh peseta didik. (Daryanto dalam Melina, 2014)."

Bahan Ajar yang selama ini digunakan oleh mahasiswa pendidikan Fisika berupa buku yang berisi tentang teori saja, dengan tampilan biasa yang di dalamnya hanya ada kalimatkalimat teori dan beberapa gambar tanpa ada tampilan pendukung yang membuat ketertarikan buku tersebut. Salah satu buku yang di dalamnya terdapat penjelasanpenjelasan materi Bumi dan Antariksa adalah Ensiklopedia. Buku tersebut hanya memuat penjelasan secara singkat istilah atau pengertian-pengertian saja yang terdapat di dalam Bumi dan Antariksa, di dalam buku tersebut kurangnya tampilan pendukung yang mampu membuat buku tersebut lebih menarik lagi. Ensiklopedia yang terdapat pada saat ini hanya berisikan teori saja tanpa adanya penjelasan yang berasal dari Al Quran, seperti kita ketahui bahwa Al Quran sebagai tuntunan manusia dan memuat informasi pokok tentang bumi dan antariksa sehingga bisa dijadikan pegangan (referensi) dalam memahami bumi dan antariksa tersebut. 
Ensiklopedia Bumi dan Antariksa berbasis Al Quran perlu dikembangkan pada mata kuliah Bumi dan Antariksa, karena pada materi di dalam perkuliahan ini sangat menarik untuk dipelajari, dan erat hubungannya dengan kehidupan nyata. Hal tersebut bisa menjelaskan adanya pemahaman yang mendalam pada mata kuliah Bumi dan Anatariksa. Berdasarkan penjelasan di atas dapat disimpulkan bahwa Sains dan Agama adalah dua sisi yang berdampingan. Keduanya merupakan bagian terpenting dalam sejarah kehidupan manusia, dan Al Quran sebagai sumber ilmu pengetahuan.

Kompetensi inti dalam kurikulum 2013 juga menekankan perlunya pengembangan sikap spiritual pada setiap peserta didik. Tujuan kurikulum 2013 adalah mempersiapkan manusia Indonesia agar memiliki kemampuan hidup sebagai pribadi dan warga negara yang beriman, produktif, kreatif, inovatif, dan efektif serta mampu berkontribusi pada kehidupan bermasyarakat, berbangsa dan bernegara dan berperadaban dunia.

Pengembangan Ensiklopedia Bumi dan Antariksa serta kaitannya dengan Al Quran, akan berisi pejelasan teori-teori yang berkaitan dengan Bumi dan Antariksa sekaligus penjelasan dari dalam Al Quran. Sasaran dalam pengembangan Ensiklopedia Bumi dan Antariksa berbasis Al Quran adalah mahasiswa Pendidikan Fisika.

Berdasarkan hasil observasi dengan menggunakan pengisian Kuisioner oleh mahasiswa Pendidkan yang dilakukan penulis di Fakultas Keguruan dan Ilmu Pendidikan, diketahui bahwa selama proses perkuliahan mahasiswa pendidikan Fisika masih terkendala dengan sumber pada mata kuliah Bumi dan Antariksa. Selanjutnya mahasiswa sangat tertarik jika nantinya buku yang dikembangkan berbentuk Ensiklopedia berbasis Al Quran, yang di dalamnya ada penjelasan materi, gambar-gambar Bumi dan Antariksa sesuai dengan penjelasan dalam sudut pandang $\mathrm{Al}$ Quran, dengan persentase sebanyak 60\% mahasiswa memilih Ensiklopedia Bumi dan Antariksa dan $40 \%$ lagi memilih buku Bumi dan Antariksa. Berdasarkan uraian di atas, maka peneliti bermaksud untuk melakukan penelitian yang berjudul "Pengembangan Ensiklopedia Pada Mata Kuliah Bumi dan Antariksa serta Kaitannya dengan Al Quran Untuk Mahasiswa Pendidikan Fisika Universitas Jambi".

\section{Metode Penelitian}

Jenis Pengembangan

"Jenis penelitian ini adalah penelitian pengembangan (Research and Development). Desain pengembangan dalam penelitian ini menggunakan model pengembangan ADDIE yang dikembangkan oleh Reiser dan Mollenda dalam Mahendra (2012)." Model pengembangan ADDIE secara garis besar terdiri dari lima fase yaitu: Analysis, Design, Development, Implementation, dan Evaluation.

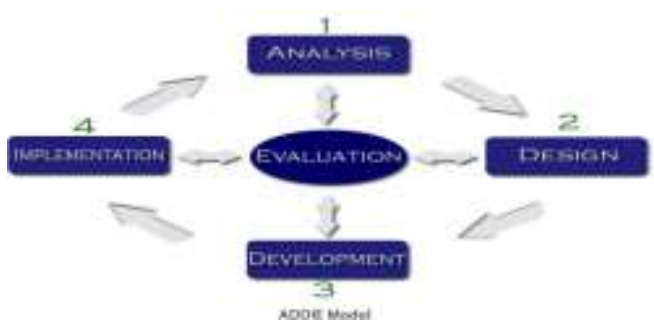

Gambar.1. Tahap Model Pengembangan ADDIE

Waktu dan Tempat Penelitian

Penelitian ini dilakukan pada tanggal 3 Juni sampai 3 Juli 2017 di FKIP Universitas Jambi.

Target/Subjek Penelitian

Target/Subjek dalam penelitian ini adalah mahasiswa pendidikan Fisika angkatan 2016 kelas reguler A dengan jumlah 39 orang.

Prosedur Pengembangan

Prosedur pengembangan yang digunakan pada penelitian ini terdiri dari empat tahapan yaitu, Analysis, Design, Development, Implementation, dan Evaluation. Tahap-tahap penelitian adalah sebagai berikut:

\section{Analysis (Analisis Pendahuluan)}

Pada tahap analisis dilakukan dua tahapan analisis yaitu:

Analisis Kebutuhan

Analisis kebutuhan dilakukan untuk mengetahui kebutuhan yang mendasar mengenai apa saja kendala yang dihadapi oleh mahasiswa pendidikan Fisika pada mata kuliah Bumi dan Antariksa, maka penulis melakukan analisis kebutuhan terhadap materi- materi Bumi dan Antariksa yang perlu dilakukan melalui observasi dengan menggunakan pengisian kusioner pada mahasiswa pendidikan Fisika, yang bertujuan untuk mendapat 
gambaran apa saja yang menjadi kendala yang dihadapi oleh mahasiswa. Kusioner yang digunakan dalam observasi terdiri dari tiga aspek yang dilihat yaitu pada proses perkuliahan, literatur yang digunakan, dan solusi yang diinginkan

\section{Analisis Mahasiswa}

Tahap analisis ini diperoleh dari hasil analisis dan observasi penulis dengan menggunakan pengisian kuisioner terhadap mahasiswa pendidikan Fisika Universitas Jambi. Dari hasil tersebut didapatkan mahasiswa pendidikan Fisika membutuhkan sumber belajar lain guna menunjang pembelajaran di rumah selain sumber internet atau buku yang didapat dari perpustakaan, selain itu juga didapatkan bahwa mahasiswa membutuhkan buku yang memiliki kapasistas seperti ensikopedia. Selanjutnya mahasiswa menginginkan nantinya di dalam ensiklopedia berisikan materi pelajaran, gambar penunjang materi, dan penjelasan dari ayat-ayat Al Quran yang berhubungan dengan materi. Berdasarkan permasalahan tersebut penulis membuat desain ensiklopedia yang sesuai dengan permintaan mahasiswa agar nantinya dapat mempermudah mahasiswa dalam memahami materi pelajaran Bumi dan Antariksa.

Hasil observasi yang didapat pada pengisian kuisioner kepada 15 orang mahasiswa pendidikan Fisika yang telah mengontrak mata kuliah Bumi dan Antariksa, didapatkan jumlah $100 \%$ mahasiswa membutuhkan literatur tambahan sebagai penunjang pembelajaran di rumah, $60 \%$ mahasiswa membutuhkan literatur berupa ensiklopedia Bumi dan Antariksa, dan 53,3\% menginginkan ensiklopedia Bumi dan Antariksa berisi materi, gambar, dan penjelasan ayat Al Quran yang berhubungan dengan materi Bumi dan Antariksa. Berdasarkan hasil tersebut maka penulis menyimpulkan bahwa untuk memecahkan permasalahan yang ada, dibuatlah suatu pengembangan berupa Ensiklopedia Bumi dan Antarika pada mata kuliah Bumi dan Antariksa yang berbasis Al Quran untuk mahasiswa pendidikan Fisika.

\section{Design (Desain)}

Pada tahan Desain dilakukan perencaanan pengembangan Perencanaan pengembangan desain produk dari pengembangan ensiklopedia pada mata kuliah Bumi dan Antariksa serta kaitannya dengan Al Quran untuk mahasiswa pendidika Fisika
Universitas Jambi, akan mencakup beberapa aspek.

Validator : Validator terdiri dari tiga orang dengan tugas dan peran masing- masing yang terdiri dari : penulis sebagai pengembang produk, Drs. Maison, M.Si. Ph.D, dan Ibu Nova Susanti S.Pd, yang bertugas untuk memvalidasi dan menilai produk yang dihasilkan,

Spesifikasi desain produk : Pada tahap ini dibuat desain produk berupa desain dari pengembang Ensiklopedia pada mata kuliah Bumi dan Antariksa serta kaitanya dengan Al Quran.

Produk yang dikembangkan memiliki spesifikasi cover menggunakan kertas jenis inkjet paper yang tidak mudah luntur jika terkena air, kertas isi menggunakan kertas jenis fhoto paper 120 gram ukuran A4 yang membuat tulisan atau warna tidak tembus kebelakang dan warna lebih cerah dan jelas, dengan ukuran kertas tersebut dapat memuat tulisan lebih banyak dan mudah dibaca. Ensiklopedia berisikan tiga bab materi yaitu: struktur bumi, sistem tata surya, asteroid dan komet. Materi disajikan secara singkat mengenai penjelasan teori sains dan dikaitkan dengan penjelasan $\mathrm{Al}$ Quran, serta didukung dengan gambar yang berhubungan dengan materi pada bab tersebut. Ensiklopedia yang dikembangkan memiliki kelebihan selain dari cover yang tidak mudah luntur jika terkena air, ukuran buku yang sedang dengan kualitas gambar yang cerah, ensiklopedia juga berisikan teori sains dan dikaitkan dengan $\mathrm{Al}$ Quran agar pembaca dapat mengetahui bahwa semua yang ada didunia telah dijelaskan dalam ayat Al Quran dan pembaca dapat termotivasi untuk memahami isi kandungan Al Quran. Serta didukung dengan gambar yang menarik.

\section{Development (Pengembangan)}

Pada tahap pengembangan dilakukan pengembangan dari ensiklopedia pada mata kuliah Bumi dan Antariksa. Ada dua tahapan yaitu sebagai berikut:

\section{Validasi Desain}

Berdasarkan prosedur pengembangan maka pada tahap pelaksanaan pengembangan dilakukan validasi terhadap desain produk melalui expert judgement (pertimbangan ahli) untuk mendapatkan data tentang hasil desain produk pada pengembangan ensiklopedia Bumi dan Antariksa pada mata kuliah Bumi dan Antariksa serta kaitanya dengan Al Quran 
untuk mahasiswa pendidikan Fisika Universitas Jambi. Melalui expert judgement ini diharapkan kualitas produk yang dibuat dapat teruji secara teoritis.

Validasi produk dapat dilakukan dengan cara mendatangi atau mengunjungi para ahli yang sudah berpengalaman untuk menilai validitas produk yang didesain tersebut. Setiap ahli diminta untuk menilai desain, sehingga selanjutnya dapat diketahui kelemahan dan kekuatannya. Pengembangan ensiklopedia Bumi dan Antariksa untuk instrumen penilaian oleh ahli media menggunakan dua indikator yaitu: tampilan ensiklopedia dan kualitas teknis, sedangkan untuk penilaian oleh ahli materi menggunakan satu indikator yaitu: kriteria pendidikan.

Secara deskripsi untuk penilaian oleh ahli media dan ahli materi adalah sebagai berikut:

Tabel 1. Kisi-kisi Instrumen Angket Ahli Media

\begin{tabular}{ll}
\hline No & Deskripsi \\
Butir & \\
\hline
\end{tabular}

1 Pemakaian warna yang menarik

2 Pemakaian warna background sudah padu dengan teks.

3 Ukuran huruf

4 Warna huruf

5 Bahasa yang baik dan benar

6 Gambar yang tidak mengganggu tampilan

$7 \quad$ Gambar yang menarik

8 Pengguna tidak merasa bosan membaca

Sumber Wahono, (2006)

Tabel 2. Kisi-kisi Instrumen Angket Oleh Ahli Materi

\begin{tabular}{ll}
\hline No & \multicolumn{1}{c}{ Deskripsi } \\
\multicolumn{1}{l}{ Butir } \\
\hline 1 & Ensiklopedia sesuai dengan silabus \\
& kurikulum \\
2 & Ensiklopedia menjelaskan terjemahan ayat \\
& Al Quran \\
3 & Kecocokan gambar dengan materi \\
4 & Ensiklopedia fleksibel terhadap pengguna \\
5 & Ensiklopedia mempunyai balikan terhadap \\
& input yang diberikan oleh pengguna \\
6 & Memungkinkan mahasiswa belajar mandiri \\
7 & Bahasa yang digunakan mudah dimengerti \\
\hline
\end{tabular}

Sumber Wahono, (2006)

\section{Revisi Desain}

Setelah diadakan validasi desain, ada yang harus diperbaiki atau ditambah guna lebih menyempurnakan produk. Revisi desain dilakukan dengan mempertimbangkan pendapat dan masukan serta penilaian dari para ahli mengenai produk. Mempertimbangkan bagian mana yang harus ditambah dan dikurang atau yang harus diperbaiki. Revisi dilakukan untuk memperbaiki kelemahan-kelemahan desain setelah diadakannya validasi dari validator.

\section{Implementation (Pelaksanaan)}

Pada tahap implementasi dilakukan uji produk kepada objek sasaran yaitu kepada mahasiswa pendidikan fisika. Uji produk dilakukan secara terbatas dengan mengambil satu angkatan mahasiswa pendidikan fisika yaitu angkatan 2016 saja yang telah mengambil mata kuliah Bumi dan Antariksa. Uji produk dilakukan untuk mengatahui seberapa besar persepsi mahasiswa mengenai produk yang telah dikembangkan berupa Ensiklopedia Bumi dan Antariksa yang berbasis Al Quran. Persepsi mahasiswa dilakukan dengan menggunakan pengisian angket yang telah dibuat oleh pengembang.

\section{Evaluation}

Evaluasi adalah proses untuk menganalisis produk yang dikembangkan pada tahap implementasi. Berdasarkan evaluasi pada saat uji coba. Dalam tahap evaluasi, data-data yang diperoleh dianalisis untuk diketahui revisi yang perlu dilakukan serta menganalisis apakah produk yang dikembangkan sudah dapat dikatakan praktis, layak, valid, dan efektif. Evaluasi pada tahap ini berupa validitas dari pengembangan Ensiklopedia Bumi dan Antariksa.

\section{Instrumen Pengumpulan Data}

Instrumen adalah alat ukur yang digunakan untuk mengukur dalam rangka pengumpulan data. Dalam penelitian ini, instrument yang digunakan adalah angket. "Angket merupakan teknik pengumpulan data yang dilakukan dengan cara memberi seperangkat pertanyaan tertulis kepada responden untuk dijawabnya" (Sugiyono, 2016). Instrumen yang digunakan dalam pengumpulan data pada penelitian ini adalah lembar validasi tim ahli dan lembar validasi untuk praktisi. Lembar validasi yang digunakan 
untuk masing-masing ahli berupa lembar validasi berupa pertanyaan-pertanyaan berkaitan dengan produk disertai dengan kolom komentar dan saran terhadap perbaikan produk. Sedangkan untuk lembar validasi praktisi juga berupa pertanyaan, namun pertanyaannya hanya berkaitan dengan praktikalitas (kegunaaan).

Jenis Data

Dalam penelitian pengembangan ini, jenis data yang diambil yaitu data kualitatif dan data kuantitatif.

\section{Data Kualitatif}

Data kualitatif diperoleh dari tim validasi yaitu tim ahli materi dan tim ahli media berupa isian angket berupa saran dalam perbaikan media.

\section{Data Kuantitatif}

Data kuantitatif diperoleh dari persepsi mahasiswa mengenai pengembang ensiklopedia Bumi dan Antariksa pada mata kuliah Bumi dan Antariksa yang berbais Al Quran untuk mahasiswa pendidikan Fisika Universitas Jambi.

\section{Teknik Analisis Data}

Data Kualitatif

"Data kualitatif berupa tanggapan, saran/masukan dari validator. Aktivitas dalam analisis data menggunakan Miles dan Huberman, yaitu data reduction, data display, dan conclusion drawing/verification. (Miles dan Huberman dalam Sugiyono, 2016) Langkahlangkah analisis data kualitatif sebagai berikut:

\section{a. Data Reduction (Reduksi Data)}

Pada observasi pendahuluan dilakukan observasi dengan pemberian angket persepsi kepada mahasiswa pendidikan Fisika, untuk mengetahui respon tentang pengembangan media ensiklopedia. Selanjutnya hasil angket persepsi tersebut dikumpulkan dan dihitung seberapa besar persentase terhadap dukungan dan respon yang baik untuk pengembangan ensiklopedia.

Pada pengembangan media dilakukan pemberian angket untuk validasi media ensiklopedia kepada tim validator. Selanjutnya hasil validator berupa tanggapan, saran/masukan dikumpulkan dan dihitung berapa koefesien validitas isi dalam penelitian ini diolah dari skor yang diberikan oleh expert judgement dengan melibatkan ahli dari bidang pendidikan (ahli konstruksi produk), dan pembelajaran (ahli media). Data penilaian dari para ahli dihitung menggunakan formula Aiken.

Media yang telah divalidasi siap untuk dicetak dan diperbanyak, dan selanjutnya media tersebut diberikan kepada mahasiswa pendidikan Fisika. Pada tahap ini mahasiswa diberikan angket persepsi untuk menilai seberapa layak dari media ensiklopedia yang dikembangkan. Selanjutnya data persepsi mahasiswa dikumpulkan dan dihitung statistik deskripsinya, serta dihitung median ideal dan simpangan baku ideal.

\section{b. Data Display (Penyajian data)}

Penyajian data pada data kualitatif disajikan dalam bentuk teks yang bersifat naratif, dan penyajian data pada data kuantitatif disajikan dalam bentuk tabel dan digram.

\section{c. Conclusing Drawing/verification}

Langkah terakhir adalah penarikan kesimpulan, kesimpulan diambil untuk menjawab dari rumusan masalah. Kesimpulan diharapkan merupakan temuan baru yang sebelumnya pernah ada.

Pada tahap observasi didapatkan hasil persentase persepsi mahasiswa terhadap media ensiklopedia yang akan dikembangkan dengan hasil sebanyak $60 \%$ mahasiswa memilih ensiklopedia Bumi dan Antariksa dan 40\% memilih buku Bumi dan Antariksa.

Pada tahap validasi media didapatkan hasil nilai validasi yang cukup baik yaitu sebesar 0,87 . Nilai tersebut diinterprestasikan sebagai koefesien yang cukup tinggi untuk produk yang dikembangkan. Selanjutnya pada tahap persepsi mahasiswa dengan jumlah 39 orang mahasiswa pendidikan Fisika. Hasil pengembangan produk ensiklopedia menghasilkan persepsi dari mahasiswa $84,61 \%$ pada kategori Baik.

\section{Data Kuantitatif}

Data kuantitatif didapat dari hasil validai dan persepsi mahasiswa, dimulai dengan melakukan pemberian angket penilaian media dan angket persepsi mahasiswa. Selanjutnya hasil persepsi dikumpulkan dan dianalisis, dengan perhitungan sebagai berikut: 
Data Hasil Validasi

Tahap I

a. Tabulasi Data

Data yang telah terkumpul selanjutnya data disusun ke dalam tabel, agar data dapat dengan mudah dihitung dan disajikan.

b. Mean

Menentukan skor rata-rata indeks Aiken yang diberikan berdasarkan penilaian dari para ahli, dirumuskan dengan perhitungan sebagai berikut: (Sujarweni dan Endrayanto, 2012)

$$
\mathrm{Me}=\frac{\sum x}{n}
$$

Keterangan:

$\mathrm{Me} \quad=$ skor rata-rata Indeks Aiken

$\Sigma x \quad=$ jumlah skor Indeks Aiken

$\mathrm{n}=$ jumlah butir pernyataan

c. Median

Menentukan posisi median dari data persepsi mahasiswa, dirumuskan dengan perhitungan sebagai berikut: (Sujarweni dan Endrayanto, 2012)

$$
\mathrm{Md}=\frac{(n+1)}{2}
$$

Keterangan:

$\mathrm{Md}=$ Median

$\mathrm{n} \quad=$ jumlah butir pernyataan

d. Modus

Perhitungan modus didapatkan dengan cara mencari jumlah data yang sering muncul.

$\mathrm{Mo}=$ jumlah data yang sering muncul

Keterangan:

Mo $=$ modus

e. Standar Deviasi

Nilai standar deviasi dari validasi media yang dikembangkan dihitung dengan menggunakan rumus sebagai berikut: (Sujarweni dan Endrayanto, 2012)

$\alpha=\sqrt{\frac{\left(x_{1}-\bar{x}\right)^{2}+\left(x_{2}-\bar{x}\right)^{2}+\cdots}{n-1}}$

Keterangan:

$\alpha \quad=$ standar deviasi $\mathrm{n} \quad=$ jumlah butir pernyataan

Nilai statistik deskriptif pada tahap validasi secara lengkap ditampilkan pada tabel 3.

Tabel 3 Hasil Statistik Deskriptif Tahap

\begin{tabular}{|c|c|c|}
\hline$\overline{\mathrm{No}}$ & $\begin{array}{l}\text { Variabel yang } \\
\text { Diamati }\end{array}$ & Jumlah \\
\hline 1 & Jumlah validator & 2 \\
\hline 2 & Nilai rata-rata Indeks Aiken & 0,87 \\
\hline 3 & Median & 8,5 \\
\hline 4 & Modus & 1 \\
\hline 5 & Standar deviasi & 0,16 \\
\hline 6 & Nilai Maksimum & 1 \\
\hline 7 & Nilai Minimum & 0,67 \\
\hline
\end{tabular}
Validasi

Tahap II

Pada tahap II "Hasil judgement ahli selanjutnya diolah menggunakan formula Aiken," (Azwar, 2015):

$V=\frac{\sum s}{[n(c-1)]}$

$$
\begin{array}{ll}
\text { Keterangan: } & \mathrm{S}=\mathrm{r}-\mathrm{I}_{0} \\
& \mathrm{I}_{0}=\underset{\text { angka penilaian validitas }}{ } \\
& \text { yang rendah } \\
\mathrm{c}= & \underset{\text { angka penilaian validitas }}{\text { tertinggi }} \\
\mathrm{r}= & \underset{\text { pengka yang diberikan oleh }}{\text { angkain }}
\end{array}
$$

"Koefesien validitas di atas 0,4-0,8 dikatakan validitas sedang, dan jika lebih besar dari 0,8 dikatakan sangat valid“(Retnawati 2016).

Data Persepsi

Tahap I

a. Tabulasi Data

Data yang telah terkumpul selanjutnya data disusun ke dalam tabel, agar data dapat dengan mudah dihitung dan disajikan. Setelah dihitung statistik deskriptif, tahap berikutnya nilai yang didapat dikonversikan kedalam level kelayakan. Perhitungan statistik deskriptif adalah sebagai berikut:

b. Mean

Menentukan skor rata-rata indikator yang diberikan berdasarkan penilaian dari persepsi mahasiswa, dirumuskan dengan perhitungan 
sebagai berikut: (Sujarweni dan Endrayanto, 2012)

$$
\mathrm{Me}=\frac{\sum x}{n}
$$

Keterangan:

$\mathrm{Me} \quad=$ skor rata-rata persepsi mahasiswa

$\Sigma x=$ jumlah skor jawaban responden

$\mathrm{n}=$ jumlah responden

c. Median

Menentukan posisi median dari data persepsi mahasiswa, dirumuskan dengan perhitungan sebagai berikut: (Sujarweni dan Endrayanto, 2012)

$$
\operatorname{Md}=\frac{(n+1)}{2}
$$

Keterangan:

Md = Median

$\mathrm{n} \quad=$ jumlah responden

d. Modus

Perhitungan modus didapatkan dengan cara mencari jumlah data yang sering muncul.

$\mathrm{Mo}=$ jumlah data yang sering muncul

Keterangan:

Mo $=$ modus

e. Standar Deviasi

Nilai standar deviasi dari validasi media yang dikembangkan dihitung dengan menggunakan rumus sebagai berikut: (Sujarweni dan Endrayanto, 2012)

$\alpha=\sqrt{\frac{\left(x_{1}-\bar{x}\right)^{2}+\left(x_{2}-\bar{x}\right)^{2}+\cdots}{n-1}}$

Keterangan:

$\alpha \quad=$ standar deviasi

$\mathrm{n} \quad=$ jumlah responden

Nilai statistik deskriptif pada tahap validasi secara lengkap ditampilkan pada tabel 4.

Tabel 4 Hasil Statistik Deskriptif Tahap Validasi

\begin{tabular}{llc}
\hline No & $\begin{array}{l}\text { Variabel yang } \\
\text { Jumlah }\end{array}$ & Diamati \\
& Jumlah Responden & 39 \\
2 & Nilai rata-rata Responden & 84,64
\end{tabular}

3 Median 2

4 Modus

5 Standar deviasi

7,03

6 Nilai Maksimum

100

7 Nilai Minimum

58

Tahap II

Mengidentifikasi kecenderungan ubahan setiap sub variabel digunakan rata-rata ideal $(M i)$ dan simpangan baku ideal $(S B i)$, dapat dihitung dengan acuan norma yaitu:

$$
\begin{aligned}
& \mathrm{Mi}=\frac{1}{2}(\text { nilai maksimum }+ \text { nilai minimum }) \\
& \left.\mathrm{SBi}=\frac{1}{6} \text { (nilai maksimum }- \text { nilai minimum }\right)
\end{aligned}
$$

Selanjutnya nilai yang didapatkan dikonversikan ke dalam tabel interval nilai level kelayakan. Terdiri dari empat level kelayakan yaitu sangat baik, baik, tidak baik dan sangat tidak baik (Azwar, 2010) Tabel interval nilai level kelayakan dapat dilihat pada tabel 5 .

Tabel 5. Interval Nilai Level Kelayakan

\begin{tabular}{lll}
\hline No & Interval Kelayakan & \multicolumn{1}{c}{ Level } \\
\hline 1 & $x \geq M i+1,5 S B i$ & Sangat Baik \\
2 & $M i \leq x<M i+1,5 S B i$ & Baik \\
3 & $M i-1,5 S B i \leq x<M i$ & Tidak Baik \\
4 & $<M i-1,5 S B i$ & Sangat Tidak Baik \\
& & \\
\hline
\end{tabular}

\section{Hasil Penelitian dan Pembahasan}

Hasil Pengembangan

Hasil pengembangan dari penelitian berupa Ensiklopedia Bumi dan Antariksa pada mata kuliah Bumi dan Antariksa dan kaitannya dengan Al Quran untuk mahasiswa pendidikan Fisika Universitas Jambi, ensiklopedia yang telah dikembangkan ditujukan untuk mahasiswa pendidikan Fisika angkatan 2016 tahun akademik 2016/2017. Pengembangan ini disusun berdasarkan pada model ADDIE. Ada beberapa langkah dalam menyusun Ensiklopedia tersebut, yaitu: (1) Analisis, (2) Desain, (3) Pengembangan, (4) Implementasi, dan (5) Evaluasi.

Tahap Analisis

Pada tahap analisis ada beberapa langkah yang harus diperhatikan diantaranya yaitu: (1) analisis kebutuhan, dan (2) analisis mahasiswa. Pada tahap analisis kebutuhan dilakukan suervei lapangan dengan melakukan 
pengisian kuisioner tentang kebutuhan buku pegangangan mengenai mata kuliah Bumi dan Antariksa, selanjutnya pada tahap analisis mahasiswa didapatkan hasil bahwa mahasiswa membutuhkan literatur yang berupa buku pegangan. Pada saat menganalisis maka peneliti mengetahui kelemahan dan kekurangan dari setiap analisis tersebut.

Tahap Desain

Tahap selanjutnya oleh peneliti adalah tahap pengembangan. Tahap desain terdiri dari tim pengembang dan spesifikasi desain produk. Dalam pengembang produk membutuhkan tim kerja yang mempunyai tugas dan peran masingmasing. Tim kerja terdiri dari 3 orang yakni peneliti sebagai pengembang produk, dan tim ahli yakni Drs. Maison, M.Si. Ph.D, dan Ibu Nova Susanti S.Pd yang bertugas memvalidasi

dan menilai produk. Tim ahli yang telah melakukan validasi terhadap produk yang telah dikembangkan oleh peneliti ini memiliki kompetensi dalam bidang pendidikan dan pembelajaran dan merupakan tenaga pengajar senior pada program studi pendidikan fisika Universitas jambi.

\section{Tahap Pengembangan}

Langkah pada tahap pengembangan yaitu, validasi desain dan desain produk. Pada tahap validasi desain yaitu validasi tim ahli terhadap desain produk melalui expert judgement (pertimbangan ahli) tentang hasil desain produk yang dikembangkan, dari hasl validasi tersebut banyak saran dan masukan baik dari ahli. Masukan dan saran tersebut disampaikan oleh ahli secara lisan melalui diskusi dengan peneliti maupun secara tulisan melalui lembar validasai yang telah dibuat oleh peneliti.

Berdasarkan saran dan masukan oleh tim ahli tersebut, maka dilakukan revisi produk untuk hasil validasi pertama dan revisi produk kedua untuk hasil validasi kedua. Setelah dilakukan revisi terhadap kedua produk sebanyak dua kali didapat komentar yang positif dari ahli baik secara lisan dan tulisan. Komentar dari tim ahli tersebut menyatakan bahwa produk tersebut secara teoritis dan isi sudah teruji validitasnya dan layak untuk digunakan.

Tahap Implementasi

Pada tahap implementasi dilakukan uji produk kepada objek sasaran yaitu kepada mahasiswa pendidikan fisika. Uji produk dilakukan secara terbatas dengan mengambil satu angkatan mahasiswa pendidikan fisika yaitu angkatan 2016 saja yang telah mengambil mata kuliah Bumi dan Antariksa. Selanjutnya dilakukan pengisian angket responden oleh mahasiswa pendidikan fisika mengenai produk yang telah dikembangkan.

\section{Tahap Evaluasi}

Tahap evaluasi dilakukan untuk mengetahui kelayakan dari produk yang dikembangkan dan diuji cobakan. Data yang telah terkumpul pada tahap implementasi dianalisis apakah produk yang dikembangkan sudah dikatakan praktis, layak, valid, dan efektif.

\section{Pembahasan}

Hasil Pembahasan Validasi Produk

Kisi-kisi ensiklopedia yang dihasilkan terlebih dahulu dilakukan telah secara kuantitatif, telaah secara kuantitatif dilakukan oleh ahli dibidangnya. Validator melakukan penilaian terhadap ensiklopedia yang dikembangkan. Lembar penilaian tersebut merupakan salah satu validitas isi. Menurut Retnawati (2016) mengungkapkan bahwa "penilaian yang dilakukan yaitu melihat kesesuaian indikator dengan tujuan pengembangan produk, kesesuaian indikator dengan cakupan materi atau kesesuain teori, melihat kesesuain produk, melihat kebenaran konsep produk, melihat kebenaran isi, kebenaran bahasa dan budaya."

Hasil penilaian selanjutnya dihitung menggunakn indeks Aiken untuk mengetahui validitas isi produk. Berdasarkan hasil analisis dapat disimpulkan bahwa "produk yang dikembangkan dinyatakan valid yaitu $\mathrm{V}>0,8$ " (Retnawati 2016) diinterprestasikan sebagai koefesien yang cukup tinggi untuk produk tersebut. Artinya produk tersebut memeiliki validitas isi yang baik dan mendukung validitas isi produk secara keseluruhan.

\section{Hasil Penilaian Produk}

Hasil penilaian produk ensiklopedia dapat disajikan dalam bentuk predikat sangat jelek sampai sangat baik. Untuk menghasilkan nilai dalam bentuk predikat tersebut dilakukan dengan cara kategori skor. Penilaian dalam penelitian ini memiliki $\theta$ Minimum 58 dan $\theta$ maksimum 100. Dengan demikian rentangan skor terbesar 100 , dan didapat nilai skor rata- 
rata dari persepsi mahasiswa 84,641, serta letak median 20 pada nilai 84 . Selanjutnya untuk konversi data pada interval nilai level kelayakan didapat rata-rata ideal sebesar 79. Rentang tersebut dibagi kedalam empat simpangan baku, diperoleh simpangan baku 26,3 sebagai simpangan baku ideal. Pemaparan lebih lengkap dapat dilihat pada Tabel 5.

Tabel 5. Interval Nilai Level Kelayakan

\begin{tabular}{lll}
\hline No & \multicolumn{1}{c}{ Interval Kelayakan } & \multicolumn{1}{c}{ Level } \\
\hline 1 & $118,5<\theta$ & Sangat Baik \\
2 & $79<\theta \leq 118,5$ & Baik \\
3 & $39,5<\theta \leq 79$ & Tidak Baik \\
4 & $0<39,5$ & Sangat Tidak Baik \\
& & \\
\hline
\end{tabular}

Hasil penilaian ensiklopedia Bumi dan Antariksa terlihat bahwa Ensiklopedia yang dikembangkan memiliki kelayakan sangat baik $0 \%$, kelayakan baik $84,61 \%$, kelayakan tidak baik $15,38 \%$, dan kelayakan sangat tidak baik $0 \%$. Selanjutnya kelayakan yang terkategorikan baik dan sangat baik adalah $84,61 \%$, berkaitan dengan penilaian kelayakan Ensiklopedia yang dikembangkan dilakukan penelusuran terhadap perolehan penilaian yang disajikan pada tabel 6 dan 7.

Tabel 6. Deskripsi Skor Rata-rata dan Media

\begin{tabular}{lc}
\hline Skor Rata-rata & Letak Median Nilai median \\
\hline 84,641 & 20 \\
\hline
\end{tabular}

Tabel 7. Deskripsi Skor Hasil Penilaian

\begin{tabular}{|c|c|c|c|}
\hline $\begin{array}{l}\text { Rata-rata } \\
\text { Max } \\
\text { Ideal }\end{array}$ & Deviasi Standar & $\theta$ Min & $\theta$ \\
\hline 79 & 26,33 & 58 & 1 \\
\hline
\end{tabular}

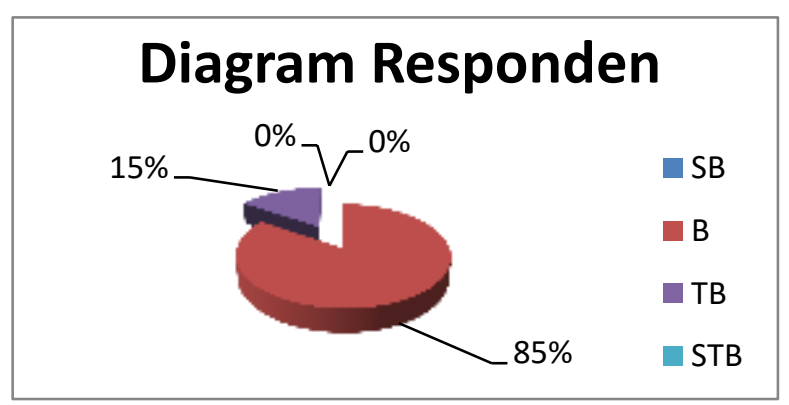

Gambar 2. Persentase Level Kelayakan
Pada gambar 2 persentasse level kelayakan terlihat persentase sebanyak $85 \%$ menilai kelayakan ensiklopedia adalah baik, sedangkan $15 \%$ menilai tidak baik.

\section{Revisi Produk}

Pada revisi produk pertama peneliti mendapatkan banyak masukan mengenai pengembangan Ensiklopedia, masukan tersebut diperoleh dari validator media dan materi. Terkait dengan masukan tersebut berupa saran yang baik untuk kelayakan ensiklopedia yang dikembangkan. Saran tersebut mengenai tambahan isi, gambar, warna dan dan tehnik penulisan dalam media ensiklopedia.

Pada revisi tahap dua peneliti masih mendapatkan masukan dari tim validator untuk pengembangan media Ensiklopedia. Masukan tersebut tidak sebanyak pada revisi produk yang pertama, disini peneliti mendapat masukan mengenai besar ukuran gambar background, cover buku, serta warna dalam media.

\section{Simpulan dan Saran}

\section{Simpulan}

Secara garis besar penelitian ini terdiri dari lima tahap utama yaitu analisis, desain, pengembangan, pelaksanaan, dan evaluasi. Pada akhirnya menghasilkan produk ensiklopedia. Produk tersebut divalidasi oleh dua orang ahli sebanyak dua kali dan dilakukan revisi hasil validasi ahli tersebut sebanyak dua kali, dan didapatkan validitas produk sebesar 0,86 pada kriteria baik.

Hasil pengembangan produk ensiklopedia menghasilkan persepsi dari mahasiswa $84,61 \%$ pada kategori Baik. Ensiklopedia yang dikembangkan tidak hanya berisikan teori sains saja namun di dalamnya juga terdapat kaitannya dengan Al Quran serta tafsir dari beberapa tafsir Al Quran, selainn itu juga terdapat gambar-gambar yang menarik sebagai penunjang materi-materi yang ada di dalam ensiklopedia Bumi dan Antarika.

Saran

Produk yang dikembangkan ini dapat digunakan dengan baik oleh mahasiswa sebagai penunjang perkuliahan, selain digunakan untuk mahasiswa produk ensiklopedia ini dapat digunakan juga oleh Dosen dan Guru.

Produk yang telah dikembangkan dapat digunakan sebagai bahan ajar oleh Dosen atau Guru disekolah. 
Produk ensiklopedia ini masih dapat dikembangkan dalam bentuk $e$-Ensiklopedia pada mata kuliah Bumi dan Antariksa

\section{Daftar Pustaka}

Azwar, Syaifudin., 2015. Reliabilitas dan Validitas. Yogyakarta: Pustaka Belajar

2010. Metode Penelitian. Yogyakarta: Pustaka Belajar

Huriawati, Farida., dan Purwandari., Permatasari Intan., 2015. Pengembangan Buku Komik Fisika Poko Bahasan Newton Berbasis Kontruktivisme Untuk Meningkatkan Motivasi Belajar Siswa, 1(2):81-89.

Melina, Fitria., Subiyanto, AA., Wujoso, Hari., 2014. Perbedaan Media Pembelajaran (Leaflet Dan Video) Terhadap Keterampilan Sadari Ditinjau Dari Motivasi. Samudra Ilmu, 5(2) Yogyakarta: Grava Media

Retnawati, Heri., 2016. Validitas Reliabilitas dan Karakteristik Butir. Yogyakarta: Parama Publishing.

Sugiyono. 2016. Metode Penelitian Pendidikan. Bandung: CV ALFABETA

Sujarweni, Wiratna V., dan Endrayanto, Poly. 2012. Statistika Untuk Penelitian. Yogyakarta: Graha Ilmu

Wahono, Romi Satria (2006). Diakses tanggal 7 November 2016. Aspek dan Kriteria Penilaian Media Pembelajaran. http://romisatriawahono.net/2006/06/2 1/aspek-dan-kriteria-penilaian-mediapembelajaran/ 